\title{
PERANAN KEPOLISIAN DALAM MENANGGULANGI TINDAK PIDANA PENYALAHGUNAAN NARKOTIKA YANG DILAKUKAN OLEH OKNUM APARAT KEPOLISIAN DI POLRES PADANG PARIAMAN
}

\author{
FAILIN \\ Sekolah Tinggi Ilmu Hukum Putri Maharaja Payakumbuh \\ failin.alin87@gmail.com
}

\begin{abstract}
Law No. 2 of 2002 concerning POLRI is regulated in full and strict regarding the duties and authorities of POLRI, but there are irregularities committed by the POLRI in carrying out its duties. Irregularities committed by POLRI is a violation of the code of ethics that is rarely heard but occurs a lot in POLRI members who are in certain cities that have a dense population. Efforts to enforce the Polri Professional Code of Ethics are needed for the realization of the implementation of the duties charged to the professionalism of POLRI. Unprocompany will greatly impact law enforcement or disclosure of crimes that occur in the community. In the framework of eradicating narcotics syndicates that have so widespread to the Unitary State of the Republic of Indonesia (NKRI), police officers have a very large role and responsibility to maintain the security and stability of the Republic of Indonesia, but facts and reality speak another that it turns out that the police themselves are the perpetrators of criminal acts of the syndicate. There has been a case that happened that the suspect is a police officer. Therefore, it is not surprising that the perpetrators of narcotics abuse crimes are increasing even among the general public but also law enforcement officials, especially the police.
\end{abstract}

Keywords: Role, Police, Countermeasures, Narcotics Crimes

\begin{abstract}
Abstrak: Undang-Undang Nomor 2 Tahun 2002 Tentang POLRI diatur dengan lengkap dan runtut mengenai tugas dan wewenang POLRI, namun ada saja penyimpangan-penyimpangan yang dilakukan oleh POLRI tersebut dalam menjalankan tugasnya. Penyimpangan yang dilakukan oleh POLRI merupakan suatu pelanggaran kode etik yang jarang didengar namun banyak terjadi pada anggota POLRI yang berada dikota-kota tertentu yang memiliki jumlah penduduk padat. Upaya penegakan Kode Etik Profesi POLRI sangat dibutuhkan untuk terwujudnya pelaksanaan tugas yang dibebankan pada profesionalisme POLRI. Ketidak profesionalisme akan sangat berdampak dalam penegakan hukum atau pengungkapan kejahatan yang terjadi dimasyarakat. Dalam rangka pemberantasan sindikat narkotika yang sudah begitu meluas sampai ke Negara Kesatuan Republik Indonesia (NKRI), aparat kepolisian memiliki peran dan tanggung jawab yang sangat besar demi menjaga keamanan dan stabilitas Negara Republik Indonesia, akan tetapi fakta dan realita berbicara lain bahwa ternyata oknum kepolisian itu sendiri yang menjadi pelaku tindak pidana dari sindikat tersebut. Sudah ada kasus terjadi yang tersangkanya aparat kepolisian. Oleh karena itu, maka tidak mengherankan jika pelaku tindak pidana penyalahgunaan narkotika semakin hari semakin meningkat bahkan bukan hanya dikalangan masyarakat umum tetapi juga aparat penegak hukum khususnya kepolisian.
\end{abstract}

Kata Kunci: Peranan, Kepolisian, Penanggulangan, Tindak Pidana Narkotika

\section{A. Pendahuluan}

Setiap individu dalam kehidupan bermasyarakat segala tingkah lakunya diatur oleh hukum, baik hukum adat di daerahnya maupun hukum yang telah diciptakan pemerintah. Sebagai patokan, hukum dapat menciptakan ketertiban dan kedamaian dalam kehidupan bermasyarakat. Hal ini sejalan dengan tujuan nasional yang termaktub dalam Pembukaan Undang-Undang Dasar 1945 yaitu melindungi segenap bangsa Indonesia dan seluruh tumpah darah Indonesia dan memajukan kesejahteraan umum, mencerdaskan kehidupan bangsa dan ikut melaksanakan ketertiban dunia yang berdasarkan kemerdekaan, perdamaian abadi dan

356 Lembaga Penelitian dan Penerbitan Hasil Penelitian Ensiklopedia $\quad$ E-ISSN: 2657-0300

P-ISSN: 2657-0319 
keadilan sosial. Bertolak dari hal tersebut, mutlak diperlukan penegak hukum dan ketertiban secara konsisten dan berkesinambungan. Perkembangan penggunaan narkotika pada saat ini tidak hanya untuk bidang kesehatan dan ilmu pengetahuan serta teknologi saja, tetapi sudah bergeser kepada tujuan untuk mencari keuntungan yang besar dengan cara menyalahgunakannya. Padahal sanksi pidana yang termuat dalam Undang-Undang Nomor 35 Tahun 2009 Tentang Narkotika memuat sanksi yang cukup berat mulai dari pidana denda, penjara seumur hidup bahkan sampai pidana mati. Pidana mati adalah upaya yang radikal untuk meniadakan orang-orang yang tak dapat diperbaiki lagi (Andi Hamzah 1994 : 27)

Peranan hukum dalam pembangunan bangsa akan membawa konsekuensi terjadinya proses perubahan dan pembaharuan pranata yang ada, termasuk fungsi hukum dan dalam pelaksanaan kebijakan pembangunan bangsa (Ediwarman, 2014 : 31). Indonesia adalah negara hukum pada hakikatnya hukum berfungsi sebagai pelindung manusia agar kepentingan manusia terlindungi, hukum harus dilaksanakan. Pelaksanaan hukum itu dapat terjadi secara normal, tetapi juga dapat terjadi karena pelanggaan hukum (Ediwarman, 2014 : 31). Setiap warga negara wajib menjunjung hukum. Kenyataan sehari-hari, warga negara yang lalai atau sengaja tidak melaksanakan kewajibannya sehingga merugikan masyarakat, dikatakan bahwa warga negara tersebut melanggar hukum karena kewajiban tersebut telah ditentukan berdasarkan hukum (Leden Marpaung 2011 : 22).

Implementasi penegakan hukum pidana materiil artinya bagi pelanggar peraturan hukum harus dijatuhi pidana, dan untuk keperluan tersebut maka hukum pidana formil dalam pelaksanaannya harus tetap melindungi hak-hak asasi tersangka atau terdakwa seperti yang dikehendaki oleh Undang-undang, salah satunya adalah hak memperoleh bantuan hukum. Upaya untuk melindungi kepentingan masyarakat agar pelaku tindak pidana tidak membahayakan dan merugikan masyarakat banyak, maka Kitab Undang-Undang Hukum Acara Pidana (selanjutnya disebut KUHAP) memberikan kewenangan bagi pihak penyidik untuk menghentikan kebebasan dan kemerdekaan tersangka atau terdakwa dalam bentuk penahanan. Namun juga KUHAP memberi kesempatan kepada tersangka atau terdakwa untuk didampingi penasehat hukum sejak pemeriksaan pendahuluan sampai pemeriksaan di pengadilan (Susilo Yuwono 1992 : 46).

Tindak pidana narkotika telah meluas dalam kehidupan masyarakat. Meluasnya tindak pidana tersebut dapat dilihat dari jumlah kasus yang terjadi, kerugian yang diderita oleh negara, maupun dari segi kualitas tindak pidana yang dilakukan secara sistematis serta ruang lingkupnya yang memasuki seluruh aspek kehidupan masyarakat. Kejahatan narkotika merupakan suatu fenomena yang komplek yang dapat dipahami dari berbagai sisi yang berbeda. Itu sebabnya dalam keseharian kita dapat menangkap berbagai komentar tentang suatu peristiwa kejahatan yang berbeda dengan yang lain. Dalam pengalaman kita ternyata tidak mudah untuk memahami kejahatan itu sendiri (Wahju Muljono $2012: 8$ ).

Bahaya dari narkotika ini telah menjadi perhatian banyak negara di dunia, termasuk Indonesia. Hal ini disebabkan karena kebanyakan korban penyalahgunaan narkotika adalah generasi muda yang merupakan generasi penerus bangsa. Dalam rangka pemberantasan sindikat narkotika yang sudah begitu meluas sampai ke Negara Kesatuan Republik Indonesia, aparat kepolisian memiliki peran dan tanggung jawab yang sangat besar demi menjaga keamanan dan kestabilan Negara Republik Indonesia. Akan tetapi pada kenyataannya berbicara lain bahwa ternyata oknum-oknum kepolisian itu sendiri yang menjadi pelaku tindak pidana dari sindikat tersebut. Oleh karena itu, tidak mengherankan jika pelaku tindak pidana penyalahgunaan narkotika semakin hari semakin meningkat bahkan bukan hanya dikalangan masyarakat umum tetapi juga aparat kepolisian.

Polisi merupakan pelaksana dan penegak hukum mempunyai tugas memelihara keamanan dalam negara Republik Indonesia serta diberikan kewenangan untuk melakukan pencegahan dan pemberantasan tindak pidana.Keberadaan polisi sebagai ujung tombak dalam posisi awal pelaksanaa sistem peradilan wajib melakukan tugas dan wewenang sebagai penegak hukum. Adanya anggota polisi yang melakukan tindak pidana penyalahgunaan narkotika sama saja oknum polisi tersebut tidak melaksanakan tugasnya dengan baik 
sebagaimana yang diatur didalam Pasal 13 Undang-Undang Nomor 2 Tahun 2002 dan Perkapolri Nomor 14 Tahun 2011 Tentang Kode Etik Polisi Republik Indonesia (Warsito Hadi Utomo 2005 : 9).

Kepolisian dalam menanggulangi atas peredaran obat-obatan terlarang, pemerintah mengeluarkan Undang-Undang Tentang Narkotika dan Psikotropika, yang mana kedua hal tersebut diatur dalam Undang-Undang No 35 Tahun 2009 Tentang Narkotika. Meskipun Undang-undang tersebut telah mencantumkan ancaman yang memberatkan bagi orang-orang yang melakukan tindak pidana penyalahgunaan narkotika dan sanksi denda yang sangatlah berat. Rekapitulasi Penyalahgunaan Narkotika yang dilakukan oleh Anggota Polri dari Tahun 2018-2021 di Polres Padang Pariaman:

\begin{tabular}{|c|c|c|c|}
\hline \multirow{2}{*}{ No. } & \multirow{2}{*}{ Tahun } & \multicolumn{2}{|c|}{ Jenis } \\
\cline { 3 - 4 } & & Shabu & Ganja \\
\hline 1. & 2018 & 6 & 1 \\
\hline 2. & 2019 & 0 & 0 \\
\hline 3. & 2020 & 1 & 0 \\
\hline 4. & 2021 & 3 & 0 \\
\hline \multicolumn{2}{|c|}{ Total } & 10 & 1 \\
\hline
\end{tabular}

Sumber: Data Polres Padang Pariaman Bulan Mei Tahun 2021

Berdasarkan tabel di atas dapat dilihat bahwa penyalahgunaan narkotika oleh aparat kepolisian di Polres Padang Pariaman dari Tahun 2018 penyalahgunana narkotika khususnya jenis shabu 6 orang dan jenis ganja 1 orang, dan di Tahun 2019 tidak terdapat penyalahgunaan narkotika yang dilakukan oleh aparat kepolisian, dan di Tahun 2020 penyalahgunana narkotika khususnya jenis shabu 1 orang dan jenis tidak ada. Namun di Tahun 2021 penyalahgunana narkotika khususnya jenis shabu 3 orang dilihat pada akhir Tahun 2021. Dalam rangka pemberantasan sindikat narkotika yang sudah begitu meluas sampai ke Negara Kesatuan Republik Indonesia (NKRI), aparat kepolisian memiliki peran dan tanggung jawab yang sangat besar demi menjaga keamanan dan stabilitas Negara Republik Indonesia, akan tetapi fakta dan realita berbicara lain bahwa ternyata oknum kepolisian itu sendiri yang menjadi pelaku tindak pidana dari sindikat tersebut. Sudah ada kasus terjadi yang tersangkanya aparat kepolisian. Oleh karena itu, maka tidak mengherankan jika pelaku tindak pidana penyalahgunaan narkotika semakin hari semakin meningkat bahkan bukan hanya dikalangan masyarakat umum tetapi juga aparat penegak hukum khususnya kepolisian.

\section{B. Metodologi Penelitian}

Untuk memudahkan membahas setiap permasalahan dalam penulisan ini, maka disamping itu pengumpulan bahan dan data-data yang erat kaitannya dengan pokok bahasan atau permasalahan dalam penulisan ini, perlu dilakukan penelitian. Adapun metode yang dilakukan dalam penelitian ini adalah yuridis empiris yakni penelitian yang menguji efektifitas hukum dalam pelaksanaannya di lapangan.

\section{Hasil dan Pembahasan}

\section{Peranan Kepolisian Dalam Menanggulangi Tindak Pidana Penyalahgunaan Narkotika yang Dilakukan Oleh Oknum Aparat Kepolisian di Polres Padang Pariaman}

Wawancara dengan Bapak IPTU Ahmad Ramadhan,S.H.,M.H sebagai Kasat Resnarkoba Polres Padang Pariaman bahwa peranan Kepolisian dalam menanggulangi tindak pidana penyalahgunaan narkotika yang dilakukan oleh oknum aparat Kepolisian di Polres Padang Pariaman adalah:

1. Melakukan pembinaan secara dini seperti: a) Melakukan pembinaan rohani dan mental dengan kegiatan berupa ceramah keagamaan terhadap seluruh personil yang dilakukan satu kali dalam satu minggu dan setiap harinya setelah pelaksanaan apel pagi dilaksanakan kegiatan tadarus Al-Qur`an; b) Melaksanakan kegiatan olahraga senam 
setiap hari dan pada hari Sabtu melaksanakan olahraga bersama terhadap seluruh personil Polres Padang Pariaman; c) Melaksanakan pengecekan urine secara mendadak terhadap personil Polres Padang Pariaman, apabila ditemukan hasil urine positif mengandung Narkoba dilakukan tindakan dan hukuman disiplin oleh Sipropam, pengecekan urine dilakukan minimal satu kali dalam satu bulan, pelaksanaannya diprioritaskan kepada personil yang terindikasi melakukan penyalahgunaan Narkoba; d) Bekerjasama dengan Bag Psikologi Biro SDM Polda Sumbar untuk melalukan pengecekan psikologi terhadap personil Polres Padang Pariaman, hal ini untuk mapping personil bermasalah dengan psikologisnya yang berpotensi melakukan penyalahgunakan Narkoba sebagai pelarian dari permasalahan tersebut; dan e) Sipropam bersama Bag Sumda Polres Padang Pariaman melakukan Konseling bagi anggota yang bermasalah, baik permasalahan pribadi, kedinasan maupun masalah keluarga.

2. Melakukan tindakan pencegahan / Preventif. Tindak lanjut yang dilakukan untuk mencegah terjadinya tindak pidana narkotika melalui pengendalian dan pengawasan oleh para Kasatker (Kepala Satuan Kerja) terhadap masing-masing anggotanya. Melakukan pemetaan / Mapping terhadap personil yang terindikasi terlibat dalam penyalahgunaan Narkotika.

3. Melakukan Penindakan / Represif. Terhadap personil Polres Padang Pariaman yang terbukti melakukan penyalahgunaan Narkoba dilakukan tindakan hukum sesuai dengan Undang-Undang Nomor 35 Tahun 2009 Tentang Narkotika. Proses hukum dilakukan sama dengan masyarakat umum. Mulai dari tahap penyidikan, penyerahan berkas kepada JPU sampai dengan tahap II (penyerahan tersangka dan barang bukti) dan disidangkan di pengadilan. Setelah mendapatkan putusan hukum dari pengadilan, secara kedinasan dilakukan proses hukuman Sidang Kode Etik Profesi Polri (KEPP) sesuai dengan Peraturan Kapolri Nomor 14 Tahun 2011 Tentang Kode Etik Kepolisian dengan ancaman hukuman tertinggi diberhentikan secara tidak hormat dari dinas Kepolisian.

Usaha penanggulangan dan pemberantasan tindak pidana narkotika secara represif, juga merupakan usaha penaggulangan kejahatan dengan hukum pidana yang pada hakekatnya merupakan bagian dari usaha pencegahan hukum (khususnya pencegahan hukum pidana narkotika). Oleh karena itu sering pula dikatakan, bahwa politik dan kebijakan hukum pidana juga yang merupakan bagian dari penegakan hukum (law enforcement policy) (Barda Nawawi Arief, 2005: 21). Pemberantasan tindak pidana narkotika yang melanggar ketentuanketentuan hukum narkotika dalam hal ini adalah usaha-usaha yang dilakukan penegak hukum dalam pemberantasan tindak pidana penyalahgunaan narkotika, serta konsekuensi yuridis terhadap pelanggaran Undang-Undang Nomor 35 Tahun 2009 Tentang Narkotika. Memahami kebijakan dalam menanggulangi tindak pidana atau kejahatan sebagaimana tersebut di atas, yaitu dengan menggunakan kebijakan penal (kebijakan hukum pidana) atau politik hukum pidana, di samping menggunakan kebijakan non penal atau kebijakan sosial. Kebijakan semacam ini juga di jumpai dalam Undang-Undang Nomor 35 Tahun 2009 Tentang Narkotika (Barda Nawawi Arief, 2005 : 25).

Polri sebagai aparat penegak hukum dituntut untuk dapat bertindak secara profesional sesuai dengan tugas dan wewenang Polri, karena itu Polri harus melakukan upaya-upaya dalam menangani tindak pidana narkotika oleh anggota Polri, Adapun upaya-upaya yang dilakukan Polri, antara lain :

1. Melakukan pembinaan secara dini. Pembinaan merupakan salah satu upaya antisipasi pencegahan dini yang dilakukan oleh Polri melalui kegiatan-kegiatan dengan tujuan menghilangkan alasan peluang dan pendorong anggota Polri melakukan tindak pidana narkotika. Tujuan dilaksakannya kegiatan ini untuk menghilangkan faktor peluang dan pendorong terkontaminasinya seseorang menjadi pengguna, serta menciptakan daya tangkal dan memotivasi, membangkitkan kesadaran anggota Polri agar tidak melakukan tindak pidana penyalahgunaan narkotika, langkah yang dilakukan dengan diadakannya tes urine bagi setiap anggota Polri, yaitu melakukan kerja sama antar polisi dalam rangka mencegah penyalahgunaan Narkoba terutama oleh Anggota Polri. Melakukan kerja sama 
dengan lembaga-lembaga swadaya masyarakat untuk melakukan penyuluhanpenyuluhan tentang bahaya penyalahgunaan narkotika, khusus personil Polres Padang Pariaman setiap pelaksanaan apel pagi selalu diberikan arahan dan penyuluhan tentang dampak, bahaya serta sangsi hukum bagi personil yang terlibat penyalahgunaan Narkoba seperti: a) Melakukan pembinaan rohani dan mental dengan kegiatan berupa ceramah keagamaan terhadap seluruh personil yang dilakukan satu kali dalam satu minggu dan setiap harinya setelah pelaksanaan apel pagi dilaksanakan kegiatan tadarus Al-Qur`an; b) Melaksanakan kegiatan olahraga senam setiap hari dan pada hari Sabtu melaksanakan olahraga bersama terhadap seluruh personil Polres Padang Pariaman; c) Melaksanakan pengecekan urine secara mendadak terhadap personil Polres Padang Pariaman, apabila ditemukan hasil urine positif mengandung Narkoba dilakukan tindakan dan hukuman disiplin oleh Sipropam, pengecekan urine dilakukan minimal satu kali dalam satu bulan, pelaksanaannya diprioritaskan kepada personil yang terindikasi melakukan penyalahgunaan Narkoba; d) Bekerjasama dengan Bag Psikologi Biro SDM Polda Sumbar untuk melalukan pengecekan psikologi terhadap personil Polres Padang Pariaman, hal ini untuk mapping personil bermasalah dengan psikologisnya yang berpotensi melakukan penyalahgunakan Narkoba sebagai pelarian dari permasalahan tersebut; e) Sipropam bersama Bag Sumda Polres Padang Pariaman melakukan Konseling bagi anggota yang bermasalah, baik permasalahan pribadi, kedinasan maupun masalah keluarga.

2. Melakukan tindakan pencegahan / Preventif. Tindakan preventif ini merupakan upaya yang lebih baik dari upaya setelah terjadinya suatu tindak pidana. Mencegah kejahatan adalah lebih baik dari pada mencoba mendidik penjahat menjadi untuk menjadi lebih baik. Lebih baik dalam artian lebih mudah, lebih murah, serta mencapai tujuan yang diinginkan. Bahkan menjadi salah satu asas dalam kriminologi yaitu usaha-usaha memperbaiki atau mendidik para penjahat untuk tidak mengulang kejahatannya. Tindak lanjut yang dilakukan untuk mencegah terjadinya tindak pidana narkotika melalui pengendalian dan pengawasan oleh para Kasatker (Kepala Satuan Kerja) terhadap masing-masing anggotanya. Melakukan pemetaan / Mapping terhadap personil yang terindikasi terlibat dalam penyalahgunaan Narkotika.

3. Melakukan Penindakan / Represif. Terhadap personil Polres Padang Pariaman yang terbukti melakukan penyalahgunaan Narkoba dilakukan tindakan hukum sesuai dengan Undang-Undang Nomor 35 Tahun 2009 Tentang Narkotika. Proses hukum dilakukan sama dengan masyarakat umum. Mulai dari tahap penyidikan, penyerahan berkas kepada JPU sampai dengan tahap II (penyerahan tersangka dan barang bukti) dan disidangkan di pengadilan. Setelah mendapatkan putusan hukum dari pengadilan, secara kedinasan dilakukan proses hukuman Sidang Kode Etik Profesi Polri (KEPP) sesuai dengan Peraturan Kapolri Nomor 14 Tahun 2011 Tentang Kode Etik Kepolisian dengan ancaman hukuman tertinggi diberhentikan secara tidak hormat dari dinas Kepolisian.

Upaya penanggulangan yang dilakukan Polres Padang Pariaman, yaitu secara penal bagi tindak pidana narkotika menitikberatkan pada upaya represif. Upaya represif antara lain meliputi rangkaian kegiatan penindakan yang ditujukan ke arah pengungkapan terhadap semua kasus tindak pidana narkotika yang telah terjadi. Tindakan penegakan hukum yang dilakukan anggota Polres Padang Pariaman dalam menanggulangi tindak pidana narkotika, yaitu melalui: a) Melakukan operasi narkotika yang ditujukan kepada tempat-tempat yang dianggap berpotensi sebagai tempat transaksi narkotika, khususnya tempat hiburan yang ada di wilayah hukum Polres Padang Pariaman; dan b) Menangkap dan menahan para pemakai dan penjual atau pengedar narkotika beserta barang bukti, lalu diadakan penyidikan dan dibuat Berita Acara Pemeriksaan (BAP) untuk diserahkan kepada Jaksa Penuntut Umum (JPU) untuk kemudian diproses di pengadilan.

Kepolisian Negara Republik Indonesia dalam menjalankan tugas dan wewenangnya di atur dalam Bab III dalam Pasal 13, Pasal 14, Pasal 15, Pasal 16, Pasal 17, Pasal 18, Pasal 19 
Nomor 2 Tahun 2002 Tentang Kepolisian Negara Republik Indonesia. Tugas pokok Kepolisian Negara Republik Indonesia adalah: a) Memelihara keamanan dan ketertiban masyarakat; b) Menegakkan hukum dan; c) Memberikan perlindungan, pengayoman dan pelayanan kepada masyarakat.

Ketentuan-ketentuan sebagai berikut: Dalam melaksanakan tugas pokok sebagaimana dimaksud dalam Pasal 13, Kepolisian Negara Republik Indonesia melakukan upaya pencegahan dan penanggulangan suatu kejahatan dengan bertugas: a) Melaksanakan pengaturan, penjagaan, pengawalan dan patroli terhadap kegiatan masyarakat dan pemerintahan sesuai kebutuhan; b) Menyelenggarakan segala kegiatan dalam menjamin keamanan, ketertiban dan kelancaran lalu lintas di jalan; c) Membina masyarakat untuk meningkatkan partisipasi masyarakat, kesadaraan hukum masyarakat serta ketaatan warga masyarakat terhadap hukum dan peraturan perundang- undangan; d) Memelihara ketertiban dan menjamin keamanan umum; e) Melakukan penyelidikan dan penyidikan terhadap semua tindak pidana sesuai dengan hukum acara pidana dan peraturan perundang-undangan lainnya; f) Melindungi keselamatan jiwa raga, harta benda masyarakat dan lingkungan hidup dari gangguan ketertiban atau bencana termasuk memberikan bantuan dan pertolongan dengan menjunjung tinggi hak asasi manusia; g) Melayani kepentingan warga masyarakat untuk sementara sebelum ditangani oleh instansi atau pihak yang berwenang; h) Memberikan pelayanan kepada masyarakat sesuai dengan kepentingannya dalam lingkup tugas kepolisian; serta i) Melaksanakan tugas lain sesuai dengan peraturan perundang-undangan.

Tugas dan wewenang kepolisian sebagai berikut: 1) Untuk kepentingan umum pejabat Kepolisian Negara Republik Indonesia dalam melaksanakan tugas dan wewenangnya dapat bertindak menurut penilaiannya sendiri; dan 2) Pelaksanaan ketentuan sebagaimana dimaksud dalam ayat 1 , hanya dapat dilakukan dalam keadaan yang sangat perlu dengan memperhatikan peraturan perundang-undangan serta Kode Etik Profesi Kepolisian Negara Republik Indonesia.

Ketentuan-ketentuan sebagai berikut: 1) Dalam melaksanakan tugas dan wewenangnya pejabat kepolisian Negara Republik Indonesia senantiasa bertindak berdasarkan norma hukum dan mengindahkan norma agama, kesopanan, kesusilaan serta menjunjung tinggi Hak Asasi Manusia; dan 2) Dalam melaksanakan tugas dan wewenang sebagaimana dimaksud dalam ayat 1, Kepolisian Negara Republik Indonesia mengutamakan tindakan pencegahan.

Fungsi kepolisian menanggulangi penyalahgunaan narkotika oleh aparat kepolisian: 1) Fungsi kepolisian disini sebagai penegak hukum; dan 2) Menindak tegas apabila terdapat aparat kepolisian menyalahgunakan narkotika.

Fungsinya sebagai aparat penegak hukum polisi wajib memahami asas-asas hukum yang digunakan sebagai bahan pertimbangan dalam pelaksanaan tugas yaitu: 1) Asas legalitas, dalam melaksanakan tugasnya sebagai penegak hukum wajib tunduk pada hukum; 2) Asas kewajiban, merupakan kewajiban polisi dalam menangani permasalahan dalam masyarakat yang bersifat diskresi, karena belum diatur dalam hukum; 3) Asas partisipasi, dalam rangka mengamankan lingkungan masyarakat polisi mengkoordinasikan pengamanan swakarsa untuk mewujudkan kekuatan hukum dikalangan masyarakat; 4) Asas Preventif selalu mengedepankan tindakan pencegahan dari pada penindakan kepada masyarakat; dan 5) Asas Subsidiaritas, melakukan tugas instansi lain agar tidak menimbulkan permasalahan yang lebih besar sebelum di tangani oleh institusi yang membidangi.

\section{Kendala dari Peranan Kepolisian Dalam Menanggulangi Tindak Pidana Penyalahgunaan Narkotika yang Dilakukan Oleh Oknum Aparat Kepolisian di Polres Padang Pariaman}

Wawancara dengan Bapak Brigadir Syafri Martoni sebagai Sipropam di Polres Padang Pariaman bahwa kendala dari peranan Kepolisian dalam menanggulangi tindak pidana penyalahgunaan narkotika yang dilakukan oleh oknum aparat Kepolisian di Polres Padang Pariaman adalah: 1) Latar belakang dan karakteristik pribadi yang dimiliki anggota Polisi membuatnya lebih cerdik dan pintar dalam melihat dan memanfaatkan situasi; 2) Kurangnya jumlah personil Sipropam selaku penegak disiplin dan pengawasan terhadap personil Polri 
sehingga kurang maksimal dalam melakukan pengawasan terhadap personil Polres Padang Pariaman, untuk saat ini jumlah personil Sipropam berjumlah 6 orang seharusnya untuk saat ini berjumlah 15 orang; 3) Kurangnya dukungan sarana prasarana berupa alat testpage urine dalam pelaksanaan pengecekan urine terhadap personil Polri. Karena tidak adanya anggaran untuk itu sehingga pada pelaksanaannya dibiayai oleh satuan terkait; 4) Para kasatker (Kepala Satuan Kerja) kurang peka terhadap permasalahan bawahannya sehingga personil Polri melakukan penyalahgunaan Narkoba sebagai pelarian dari permasalahannya; 5) Kurangnya koordinasi dilapangan dan keterbatasan personil penyidik Sat Resnarkoba juga menjadi salah satu kendala dalam mengungkap kasus peredaran tindak pidana narkotika pada saat akan mengadakan operasi-operasi di tempat-tempat yang menjadi objek sasaran.

Masalah-masalah yang berhubungan dengan kendala dalam menanggulangi penyalahgunaan narkotika, tidak terlepas dari kelemahan-kelemahan yang ada dalam tubuh lembaga kepolisian itu sendiri, baik yang menyangkut struktur organisasi maupun yang menyangkut dengan personelnya tersebut. Kendala yang dihadapi oleh Polres Padang Pariaman dalam menanggulangi penyalahgunaan tindak pidana narkotika oleh oknum aparat kepolisian, yaitu:

1. Latar belakang dan karakteristik pribadi yang dimiliki anggota Polisi membuatnya lebih cerdik dan pintar dalam melihat dan memanfaatkan situasi. Karena sebagai aparat kepolisian harus mengetahui sanksi pidana terhadap penyalahgunaan dan peredaran gelap narkotika di dalam Undang-Undang Nomor 35 Tahun 2009 Tentang Narkotika. Penanganan pemberian sanksi pidana terhadap oknum Polri yang menyalahgunakan narkotika diberlakukan Undang-Undang Nomor 35 Tahun 2009 Tentang Narkotika. Didalam ketentuan tersebut tidak hanya berlaku bagi anggota kepolisian, akan tetapi bagi masyarakat lain juga yang terbukti telah menyalahgunakan narkotika.

2. Kurangnya jumlah personil Sipropam selaku penegak disiplin dan pengawasan terhadap personil Polri sehingga kurang maksimal dalam melakukan pengawasan terhadap personil Polres Padang Pariaman, untuk saat ini jumlah personil Sipropam berjumlah 6 orang seharusnya untuk saat ini berjumlah 15 orang.

3. Kurangnya dukungan sarana prasarana berupa alat testpage urine dalam pelaksanaan pengecekan urine terhadap personil Polri. Dalam hal ini karena tidak adanya anggaran untuk itu sehingga pada pelaksanaannya dibiayai oleh satuan terkait, padahal ini sangat menentukan stabilitas kondisi secara fisik bagi aparat kepolisian dalam menjalankan tugasnya sebagai penegak hukum. Ketentuan pidana narkotika (bentuk tindak pidana yang dilakukan serta ancaman sanksi pidana bagi pelakunya) yang diatur dalam UndangUndang Nomor 35 Tahun 2009 tercantum dalam beberapa pasal. Pasal-pasal tersebut antara lain Pasal 111 - Pasal 127, Pasal 129 dan Pasal 137. Di samping sanksi pidana yang tercantum pada Undang-Undang Nomor 35 Tahun 2009, kepada oknum Polri yang menyalahgunakan narkotika juga diberikan sanksi administratif yaitu sanksi yang diberikan oleh instansi yang bersangkutan, sesuai dengan tugas pokok Polri yang tercantum pada Pasal 13 huruf b yakni menegakkan hukum, maka setiap anggota Polri dituntut untuk mampu melakukan penyelidikan dan penyidikan terhadap setiap bentuk tindak pidana, hal tersebut akan sangat bertolak belakang jika anggota Polri sendiri yang melakukan tindak pidana, karena seharusnya Polri menjadi panutan masyarakat dalam melaksanakan hukum dan peraturan yang berlaku.

4. Para kasatker (Kepala Satuan Kerja) kurang peka terhadap permasalahan bawahannya sehingga personil Polri melakukan penyalahgunaan Narkoba sebagai pelarian dari permasalahannya. Hukum berlaku bagi siapa saja yang melanggar tidak terkecuali bagi anggota kepolisian, sehingga selain dikenakan sanksi yang tercantum dalam UndangUndang Nomor 35 Tahun 2009 juga diberikan sanksi administratif bagi aparat tersebut dari instansi yang bersangkutan. Penerapan hukum selain Undang-Undang Nomor 35 Tahun 2009, tata cara mengadili mengacu pada Kitab Undang-Undang Hukum Acara 
Pidana (KUHAP) dapat dilihat pada ketentuan dalam Undang-Undang Nomor 2 Tahun 2002 Tentang Kepolisian Negara.

5. Kurangnya koordinasi dilapangan dan keterbatasan personil penyidik Sat Resnarkoba juga menjadi salah satu kendala dalam mengungkap kasus peredaran tindak pidana narkotika pada saat akan mengadakan operasi-operasi di tempat-tempat yang menjadi objek sasaran.

Ada beberapa tindakan yang akan dikenakan pada oknum polisi tersebut yaitu dijerat dengan Peraturan Kepolisian, dibawa ke sidang profesi atau sidang disiplin di mana dalam hal ini ancaman hukuman dijatuhkan sesuai dengan hasil keputusan sidang, pemberhentian tidak dengan hormat (PTDH), jika oknum tersebut dijatuhkan hukuman oleh Hakim dengan hukuman 5 (lima) tahun penjara atau lebih, maka oknum tersebut dapat dipecat dari instansi tetapi jika hukuman yang dijatuhkan kurang dari 5 (lima) tahun maka oknum tersebut dapat dipertimbangkan lagi oleh instansi dan penurunan pangkat serta jika terbukti menggunakan narkoba maka oknum polisi tersebut dimutasi ke tempat yang jauh dari narkoba atau tidak ada narkobanya.

Oknum polisi yang terbukti menggunakan narkotika berarti telah melanggar aturan disiplin dan kode etik, karena setiap anggota Polri wajib menjaga tegaknya hukum serta menjaga kehormatan, reputasi, dan martabat Polri. Pelanggaran terhadap aturan disiplin dan kode etik akan diperiksa, bila terbukti akan dijatuhi sanksi. Penjatuhan sanksi disiplin atas pelanggaran kode etik tidak menghapus tuntutan pidana terhadap anggota polisi yang bersangkutan Pasal 12 ayat (1) Peraturan Pemerintah Nomor 2 Tahun 2003 jo. Pasal 28 ayat (2) Perkapolri Nomor 14 Tahun 2011, oleh karena itu, oknum polisi yang menggunakan narkotika, akan diproses hukum acara pidana walaupun telah menjalani sanksi disiplin dan sanksi pelanggaran kode etik.

Oknum polisi disangkakan menggunakan narkotika diproses penyidikan tetap harus dipandang tidak bersalah sampai terbukti melalui putusan pengadilan yang telah berkekuatan hukum tetap (asas praduga tidak bersalah) sebagaimana diatur Pasal 8 ayat (1) Undang Undang Nomor 48 Tahun 2009 Tentang Kekuasaan Kehakiman. Apabila putusan pidana terhadap oknum polisi tersebut telah berkekuatan hukum tetap, ia terancam diberhentikan tidak dengan hormat berdasarkan Pasal 12 ayat (1) huruf a Peraturan Pemerintah Nomor 1 Tahun 2003 Tentang Pemberhentian Anggota Kepolisian Negara Republik Indonesia. Keputusan hukuman untuk personil yang melakukan pelanggaran disiplin, ada beberapa hukuman yang diatur dalam Peraturan Pemerintah Nomor 2 Tahun 2003 Tentang peraturan disiplin anggota polri berupa: 1) Teguran tertulis, 2) Penundaan mengikuti pendidikan paling lama 1 tahun, 3) Penundaan kenaikan gaji berkala, penundaan kenaikan pangkat paling lama 1 tahun, 4) Mutasi yang bersifat domisi, 5) Pembebasan dari jabatan, dan 6) Penempatan dalam tempat khusus paling lama 21 hari.

Jika putusan penegakan disiplin sudah ada, maka si pelanggar wajib mengikuti atau mentaati putusan hukuman pelanggaran disiplin yang diberikan kepada mereka. Karena keputusan hukum disiplin sudah diatur dalam Peraturan Kepala Polisi Negara Republik Indonesia (PERKAP) No 2 Tahun 2016 Pasal 66 dan 69. Kemudian apabila si pelanggar merasa hukuman yang diberikan tidak sesuai dengan pelanggaran yang ia terima, si pelanggar diperbolehkan untuk mengajukan keberatan atas penjatuhan hukuman yang ia terima. Pengajuan keberatan diperbolehkan karena juga diatur dalam PERKAP Nomor 2 Tahun 2016 Pasal 68.

Apabila ada personil yang sudah terbukti melakukan pelanggaran disiplin dan tidak melaksanakan hukuman yang diberikan seperti penempatan khusus, maka akan dilakukan upaya paksa oleh personil Propam kepada si pelanggar. Karena untuk hukuman penundaan pendidikan dan penundaan kenaikan gaji adalah merupakan hukuman administrasi. Saat peneliti mewawancarai Bapak Brigadir Syafri Martoni sebagai Sipropam Polres Padang Pariaman, mengenai hal ini, beliau mengatakan sejauh ini tidak ada pelanggar disiplin yang tidak menjalankan hukuman yang ia terima. Karena seperti penundaan kenaikan gaji dan penundaan pendidikan itu adalah merupakan hukuman administrasi. Kemudian untuk 
penempatan khusus sampai saat ini para terduga pelanggar disiplin menjalankan hukuman penempatan khusus mereka di ruangan tahanan yang juga dihuni oleh tahanan umum.

Kemudian, Bapak Brigadir Syafri Martoni sebagai Sipropam Polres Padang Pariaman, juga menyampaikan bahwa apabila saat terduga pelanggar sudah dijatuhi hukuman disiplin dan terduga pelanggar merasa ia keberatan, terduga pelanggar boleh mengajukan keberatan tehadap hukuman disiplin yang diajukan oleh terduga pelanggar melalui Ankum kepada Atasan Ankum. Terduga pelanggar memiliki waktu selama 14 hari setelah penjatuhan hukuman disiplin untuk mengajukan keberatan terhadap hukuman yang diterima. Kemudian apabila terduga pelanggar mengajukan keberatan, kemudian Atasan Ankum menerima keberatan yang diajukan terduga pelanggar seluruhnya, Atasan Ankum membatalkan putusan Ankum dan mengembalikan semua hak terduga pelanggar. Artinya terduga pelanggar terbukti tidak melakukan pelanggaran disiplin. Lalu jika Atasan Ankum menolak keberatan yang diajukan oleh terduga pelanggar seluruhnya, Atasan Ankum menguatkan putusan dari Ankum. Atasan Ankum dapat mengubah putusan Ankum apabila Atasan Ankum menerima/menolak sebagian keberatan dari terduga pelanggar dan keputusan Atasan Ankum merupakan keputusan akhir yang tidak dapat diganggu gugat. Beliau juga menyampaikan bahwa apabila dalam 14 hari tersebut terduga pelanggar tidak mengajukan keberatan, dihari ke 15 setelah penjatuhan hukuman, secara otomatis hukuman yang telah diberikan kepada terduga pelanggar mulai berlaku dan sipelanggar wajib mengikuti hukuman yang ia terima.

\section{Upaya yang Dilakukan dalam Mengatasi Kendala dari Peranan Kepolisian Dalam Menanggulangi Tindak Pidana Penyalahgunaan Narkotika yang Dilakukan Oleh Aparat Kepolisian di Polres Padang Pariaman}

Wawancara dengan Bapak IPTU Ahmad Ramadhan,S.H.,M.H sebagai Kasat Resnarkoba Polres Padang Pariaman bahwa upaya yang dilakukan dalam mengatasi kendala dari peranan Kepolisian dalam menanggulangi tindak pidana penyalahgunaan narkotika yang dilakukan oleh aparat Kepolisian di Polres Padang Pariaman adalah: 1) Melakukan pengawasan yang ketat terhadap setiap anggota kepolisian. Pengawasan juga berperan penting dalam menanggulangi penyalahgunaan narkotika tersebut; 2) Melakukan penambahan jumlah personil Sipropam selaku penegak disiplin dan pengawasan terhadap personil Polri sehingga pengawasan terhadap personil bisa efektif; 3) Melakukan penambahan sarana dan prasarana serta anggaran dalam penyediaan alat testpage urine dalam pelaksanaan pengecekan urine terhadap personil Polri agar seluruh personil bisa diketahui secara pasti; 4) Melakukan penyuluhan terhadap aparat Kepolisian setiap saat apapun kesempatan sehingga selalu diingat oleh aparat yang bersangkutan; dan 5) Sipropam melakukan pengecekan urine secara mendadak terhadap personil yang diduga kuat terlibat dalam penyalahgunaan Narkoba, memberikan tindakan dan hukuman disiplin apabila hasil pengecekan urine positif mengandung unsur Narkoba, dalam hal ini tidak dijadwalkan karena selalu dilakukan kapan saja ada kesempatan.

Upaya mengatasi kendala oleh Polres Padang Pariaman dalam menanggulangi penyalahgunaan tindak pidana narkotika oleh aparat kepolisian adalah:

1. Melakukan pengawasan yang ketat terhadap setiap anggota kepolisian. Pengawasan juga berperan penting dalam menanggulangi penyalahgunaan narkotika tersebut. Oknum polisi yang menggunakan narkotika berarti telah melanggar aturan disiplin dan kode etik, oleh karena setiap anggota polri wajib menjaga tegaknya hukum serta menjaga kehormatan, reputasi, dan martabat Kepolisian Republik Indonesia sesuai dengan Pasal 5 huruf a Peraturan Pemerintah Nomor 2 Tahun 2003 jo. Pasal 6 dan Pasal 7 Perkapolri Nomor 14 Tahun 2011. Pelanggaran terhadap aturan disiplin dan kode etik akan diperiksa dan bila terbukti akan dijatuhi sanksi. Penjatuhan sanksi disiplin serta sanksi atas pelanggaran kode etik tidak menghapus tuntutan pidana terhadap anggota polisi yang bersangkutan sesuai Pasal 12 ayat (1) Peraturan Pemerintah Nomor 2 Tahun /2003 jo. Pasal 28 ayat (2) Perkapolri Nomor 14 Tahun 2011, oleh karena itu, oknum polisi 
yang menggunakan narkotika tetap akan diproses hukum acara pidana walaupun telah menjalani sanksi disiplin dan sanksi pelanggaran kode etik.

2. Melakukan penambahan jumlah personil Sipropam selaku penegak disiplin dan pengawasan terhadap personil Polri sehingga pengawasan terhadap personil bisa efektif. Jumlah personil sangat berpengaruh terhadap oknum polisi yang disangkakan/tidak menggunakan narkotika dan diproses penyidikan tetap harus dipandang tidak bersalah sampai terbukti melalui putusan pengadilan yang telah berkekuatan hukum tetap asas praduga tidak bersalah sebagaimana diatur Pasal 8 ayat (1) Undang-Undang Nomor 48 Tahun 2009 Tentang Kekuasaan Kehakiman.

3. Melakukan penambahan sarana dan prasarana serta anggaran dalam penyediaan alat testpage urine dalam pelaksanaan pengecekan urine terhadap personil Polri agar seluruh personil bisa diketahui secara pasti.

4. Melakukan penyuluhan terhadap aparat Kepolisian setiap saat apapun kesempatan sehingga selalu diingat oleh aparat yang bersangkutan. Adanya penegakan hukuman disiplin terhadap pelanggaran peraturan disiplin haruslah secara tegas dan berdasarkan peraturan perundang-undangan agar tidak melanggar hak-hak yang dimiliki anggota Polri. Dengan begitu perlu juga untuk diperhatikan adanya suatu kewenangan penegakan hukuman disiplin tetap berada di jalurnya dan tidak disalahgunakan.

5. Sipropam melakukan pengecekan urine secara mendadak terhadap personil yang diduga kuat terlibat dalam penyalahgunaan Narkoba, memberikan tindakan dan hukuman disiplin apabila hasil pengecekan urine positif mengandung unsur Narkoba, dalam hal ini tidak dijadwalkan karena selalu dilakukan kapan saja ada kesempatan

Peraturan perundang-undangan yang memuat tindak pidana diluar KUHP berbeda dengan KUHP, dalam rumusannya selain mengatur segi-segi hukum materil (perumusan tindak pidana dan macam-macam pidana) kadang juga mengatur secara khusus tentang segisegi hukum pada formil yaitu: bagaimana cara melaksanakan hukum pidana materil yaitu Penyelidikan, penuntutan, mengadili perkara dan lain-lain tapi sebagian besar masih mengacu pada KUHAP. Adanya ketentuan mengenai pidana khusus diluar KUHP merupakan perluasan secara kuantitatif mengikuti perkembangan dan kebutuhan masyarakat (Tina Asmarawati 2004 :11).

Prosedur pemeriksaan oknum kepolisian yang menggunakan narkotika, yaitu sesuai dengan Pasal 29 ayat (1) Undang-Undang Nomor 2 Tahun 2002 Tentang Kepolisian Negara Republik Indonesia, anggota Kepolisian Negara Republik Indonesia tunduk pada kekuasaan peradilan umum, hal ini menunjukkan bahwa anggota polri merupakan warga sipil dan bukan termasuk subjek hukum militer. Meskipun anggota kepolisian termasuk warga sipil, namun terhadap mereka juga berlaku ketentuan peraturan disiplin dan kode etik profesi. peraturan disiplin Polri diatur dalam Peraturan Pemerintah Nomor 2 Tahun 2003 Tentang Peraturan Disiplin Anggota Kepolisian Negara Republik Indonesia, sedangkan, kode etik kepolisian diatur dalam Perkapolri Nomor 14 Tahun 2011 Tentang Kode Etik Profesi Kepolisian Negara Republik Indonesia.

Sanksi pidana terhadap penyalahgunaan narkotika untuk diri pribadi diatur Pasal 127 ayat (1) Undang-Undang Nomor 35 Tahun 2009 Tentang Narkotika. Guna tercapainya keadilan hukum dalam setiap pelanggaran kode etik profesi polisi dilaksanakan secara objektif dan menjunjung tinggi keadilan serta memperhatikan jasa anggota polisi yang melanggar kode etik profesi Polri dan berapa banyak keterlibatanya dalam masalah hukum yang menjeratnya. Pasal 17 ayat 1 Perkap Nomor 14 Tahun 2011 Tentang Kode Etik Profesi Polri, yang berhak melakukan penegakan kode etik Polri adalah: a) Propam Polri; b) Komisi kode etik profesi; c) Komisi banding; d) Pengembangan fungsi hukum Polri; e) Sumber Daya Manuasia anggota Polri; dan f) Propram Polri dibidang rehabilitasi.

Upaya-upaya tersebut dilakukan Propam Kepolisian Padang Pariaman untuk menciptakan good governmant dan berdasarkan visi dari polri yang melindungi, mengayomi, dan melayani masyarakat, serta menjadi aparat penegak hukum. Adapun upaya strategis untuk mewujudkan hal tersebut, banyak upaya yang dilakukan Propam Kepolisian Padang Pariaman. 
Menurut hasil wawancara dengan Brigadir Syafri Martoni sebagai Provos Polres Padang Pariaman menerangkan bahwa upaya yang dilakukan adalah antara lain, melakukan tes urine selama 2 bulan sekali, melakukan pengecekan kehadiran anggota pada saat ada kegiatan dan apel, melakukan penyuluhan hukum terkait dengan peraturan Kapolri, dan yang paling penting adalah memberikan reward and punishment kepada tiap anggota. Pemberian reward and punishment merupakan program dari Kepolisian Padang Pariaman untuk meningkatkan kinerja anggota kepolisian, citra, dan dapat mewujudkan anggota Kepolisian Padang Pariaman bertugas sesuai dengan kewajibannya berdasarkan aturan hukum yang berlaku. Kinerja yang diharapkan adalah anggota kepolisian mampu melaksanakan tribrata yaitu melindungi masyarakat, melayani masyarakat dan mengayomi masyarakat serta dapat melaksanakan tugas pokok dan fungsi sebagai anggota kepolisian.

Selain itu program ini juga dapat meningkatkan citra kepolisian sebagai lembaga yang mampu bersinergi dengan masyarakat. Program pemberian reward and punishment dapat memberikan kepercayaan kepada masyarakat bahwa kepolisian telah melakukan kinerjanya sesuai dengan cita-cita Kepolisian Negara Republik Indonesia yaitu menciptakan lembaga yang baik dan jujur. Disamping itu upaya yang harus dilakukan untuk meningkatkan kemampuan Bidang. Propam Padang Pariaman dalam mendukung tugas operasional Polri, sesuai dengan tugas dan tanggung jawabnya sebagai pengembang fungsi pengamanan ke dalam, harus memiliki personil yang mempunyai kemampuan mendeteksi secara dini dan mampu melakukan kegiatan penyelidikan, pengamanan dan penggalangan. Adapun cara untuk meningkatkan kemampuan personil melalui berikut ini.

Pendidikan. Untuk meningkatkan kualitas personil, harus ada upaya yang dilakukan agar anggota mempunyai kemampuan menditeksi secara dini, melakukan kegiatan penyelidikan, pengamanan dan penggalangan. Adapun cara untuk meningkatkan kemampuan personil sesuai yang diharapkan antara lain melalui: a) Memberikan kesempatan mengikuti pendidikan pengembangan maupun pendidikan kejuruan provos terhadap para Perwira dan Brigadir personil Bid Propam; b) Mengadakan Pelatihan-pelatihan kepada Unit-unit Operasional dalam upaya meningkatkan kemampuan personil pada kegiatan-kegiatan penyelidikan dan penyajian data untuk dijadikan produk; c) Memberikan kesempatan untuk mengikuti Pendidikan umum Program Sarjana (S1, S2, S3) serta Pendidikan luar negeri dengan biaya dinas; dan d) Mengikutsertakan personil dalam kegiatan-kegiatan ilmiah di bidang hukum, seperti kegiatan seminar, diskusi dan lokakarya dengan maksud menambah wawasan dan pengetahuan personil khususnya Perwira, disamping itu dapat mengetahui dan mengikuti perkembangan perubahan yang terjadi pada masyarakat umum maupun pada tubuh Polri itu sendiri.

Pelatihan. Mengadakan pelatihan-pelatihan terhadap unit operasional dalam rangka meningkatkan kemampuan personil meliputi: a) Kemampuan Penyelidikan: 1) Pemberian teori perencanaan pengumpulan bahan keterangan; 2) Pemberian teori dan praktek, tehnik dan taktik penyelidikan; 3) Praktek penyamaran (Under cover job, Story, place); 4) Praktek Pembuntutan (Survelen) dengan sistim A,B,C; 5) Latihan Pengamatan dan Penggambaran (Matbar) terhadap suatu obyek; 6) Latihan Penyusupan; dan 7) Latihan dengan sasaran nyata; b) Meningkatkan kemampuan pengamanan: 1) Latihan penyusunan rencana pengamanan (Renpam). 2) Latihan penentuan ploting anggota terhadap obyek mako atau gedung; 3) Praktek pengamanan terhadap kegiatan maupun Pejabat Polri; dan 4) Latihan dengan sasaran nyata.

\section{Penutup}

Berdasarkan pembahasan tersebut di atas, maka penulis telah menarik kesimpulan terkait kedua permasalahan hukum bangunan di atas air sebagai berikut: Peranan Kepolisian dalam menanggulangi tindak pidana penyalahgunaan narkotika yang dilakukan oleh aparat Kepolisian di Polres Padang Pariaman adalah dengan melakukan pembinaan secara dini melalui kegiatan-kegiatan dengan tujuan menghilangkan alasan peluang dan pendorong anggota Polri melakukan tindak pidana narkotika dan melakukan tindakan pencegahan dan penindakan melalui pengendalian dan pengawasan oleh para Kasatker (Kepala Satuan Kerja) 
terhadap masing-masing anggotanya. Melakukan pemetaan / Mapping terhadap personil yang terindikasi terlibat dalam penyalahgunaan Narkotika. Kendala dari peranan Kepolisian dalam menanggulangi tindak pidana penyalahgunaan narkotika yang dilakukan oleh aparat Kepolisian di Polres Padang Pariaman adalah latar belakang dan karakteristik pribadi yang dimiliki anggota Polisi membuatnya lebih cerdik dan pintar dalam melihat dan memanfaatkan situasi, kurangnya jumlah personil Sipropam selaku penegak disiplin dan pengawasan terhadap personil Polri sehingga kurang maksimal dalam melakukan pengawasan terhadap personil Polres Padang Pariaman, untuk saat ini jumlah personil Sipropam berjumlah 6 orang seharusnya untuk saat ini berjumlah 15 orang, kurangnya dukungan sarana prasarana berupa alat testpage urine dalam pelaksanaan pengecekan urine terhadap personil Polri. Karena tidak adanya anggaran untuk itu sehingga pada pelaksanaannya dibiayai oleh satuan terkait, para kasatker (Kepala Satuan Kerja) kurang peka terhadap permasalahan bawahannya sehingga personil Polri melakukan penyalahgunaan Narkoba sebagai pelarian dari permasalahannya dan kurangnya koordinasi dilapangan dan keterbatasan personil penyidik Sat Resnarkoba juga menjadi salah satu kendala dalam mengungkap kasus peredaran tindak pidana narkotika pada saat akan mengadakan operasi-operasi di tempat-tempat yang menjadi objek sasaran Upaya yang dilakukan dalam mengatasi kendala dari peranan Kepolisian dalam menanggulangi tindak pidana penyalahgunaan narkotika yang dilakukan oleh aparat Kepolisian di Polres Padang Pariaman adalah dengan melakukan pengawasan yang ketat terhadap setiap anggota kepolisian. Pengawasan juga berperan penting dalam menanggulangi penyalahgunaan narkotika tersebut, melakukan penambahan jumlah personil Sipropam selaku penegak disiplin dan pengawasan terhadap personil Polri sehingga pengawasan terhadap personil bisa efektif, melakukan penambahan sarana dan prasarana serta anggaran dalam penyediaan alat testpage urine dalam pelaksanaan pengecekan urine terhadap personil Polri agar seluruh personil bisa diketahui secara pasti, melakukan penyuluhan terhadap aparat Kepolisian setiap saat apapun kesempatan sehingga selalu diingat oleh aparat yang bersangkutan dan Sipropam melakukan pengecekan urine secara mendadak terhadap personil yang diduga kuat terlibat dalam penyalahgunaan Narkoba, memberikan tindakan dan hukuman disiplin apabila hasil pengecekan urine positif mengandung unsur Narkoba, dalam hal ini tidak dijadwalkan karena selalu dilakukan kapan saja ada kesempatan.

\section{Daftar Pustaka}

Andi Hamzah, dkk, 1994, Pidana Mati di Indonesia di Masa Lalu, Kini, dan Masa Depan, Ghalia Indonesia, Jakarta.

Dewi Bunga, 2012, Prostitusi Cyber Penegakan Hukum Dalam Anatomi Kejahatan Transnasional, Udayana University Press, Denpasar.

Ediwarman, 2014, Penegakan Hukum dalam Perspektif Kriminologi, Genta Publishing, Yogyakarta.

Hari Sasanka, 2003, Narkotika dan Psikotropika Dalam Hukum Pidana, Mandar Maju, Bandung.

Kansil. C.S.T, 1992, Pengantar Ilmu Hukum dan Tata Hukum Indonesia, Balai Pustaka, Jakarta.

Laden Marpaung, 2005, Asas Teori-Praktik Hukum Pidana, Sinar Grafika, Jakarta. 2011, Proses Penanganan Perkara Pidana (Penyidikan dan Penyelidikan), Cetakan Ketiga, Sinar Grafika, Jakarta.

Lamintang, P.A.F. 1997, Dasar-Dasar Hukum Pidana Indonesia, Citra Aditya Bakti, Bandung.

Liliana Tedjosaputro, 1995, Penegakan Hukum, PT Bayu Indra Grafika, Yogyakarta.

Poerwagarminto, 1989, Kamus Besar Bahasa Indonesia, Balai Pustaka, Jakarta.

Romli Atmasasmita, 1989, Asas-asas Perbandingan Hukum Pidana, Yayasan LBH, Jakarta.

Soerjono Soekanto, 1983, Pengantar Penelitian Hukum, Rineka Cipta. Jakarta.

2006, Hukum Acara Pidana, Badan Penerbit Universitas Diponegoro,

Semarang

E-ISSN: 2657-0300 Lembaga Penelitian dan Penerbitan Hasil Penelitian Ensiklopedia 
Siswo Wiratmo, 1990, Pengantar Ilmu Hukum, FH. UII, Yogyakarta.

Susilo Yuwono, 1992, Penyelesaian Perkara Pidana Berdasarkan KUHAP, Sistem dan Prosedur, Penerbitan Alumni, Bandung.

Sutanto, 2007, Hukum Kepolisian Profesionalisme dan Reformasi POLRI, Laksbang Mediatama, Surabaya.

Teguh Prastyo, 2011, Hukum Pidana, Rajawali Pers, Jakarta.

Tina Asmarawati, 2004, Delik-Delik Yang Berada Di Luar KUHP, Budi Utama, Yogyakarta.

Wahju Muljono, 2012, Pengantar Teori Kriminologi, Pustaka Yustisia, Yogyakarta.

Warsito Hadi Utomo, 2005, Hukum Kepolisian di Indonesia, Prestasi Pustaka Publisher, Jakarta.

WJS. Peorwadarminta, 1985, Kamus Umum Bahasaa Indonesia, Eresco, Jakarta.

Kitab Undang-Undang Hukum Pidana

Undang-Undang Nomor 8 Tahun 1981 Tentang Hukum Acara Pidana

Undang-Undang Nomor 35 Tahun 2009 Tentang Narkotika

Perkapolri Nomor 14 Tahun 2011 Tentang Kode Etik Polisi Republik Indonesia.

Andi Munwarman, Sejarah Singkat POLRI .http:/ /www.HukumOnline.com / hg/narasi/ 2004/04/21/nrs,20040421-01, id. html.

http://ejurnal.bunghatta.ac.id/index.php?journal=JFH\&page=article \&op=viewFile \&path[]=412 $7 \&$ path[]=3497.

https://jauhinarkoba.com/pemicu-terjadinya-penyalahgunaan-narkoba/.

http://www.hukumonline.com/klinik/detail/lt511cf005d88bc/proses-hukum oknum polisiyang-melakukan-tindak-pidana

Wisnu Jati Dewangga, Penegakan Hukum Tindak Pidana Penyalahgunaan Narkotika Dengan Pelaku Anggota Kepolisian (Studi Kasus Di Wilayah Hukum Boyolali), Jurisprudence, Vol. 4 No. 2 September 2014, 